\title{
NOTES
}

\section{TORTS: INDUCING BREACH OF ATTORNEY-CLIENT CONTINGENT FEE CONTRACTS}

$\mathrm{I}_{\mathrm{N}}$ Herron v. State Farm Mut. Ins. Co. ${ }^{1}$ an attorney brought suit for intentional interference with contractual relations. The plaintiff alleged that an agent of the defendant in settling with the plaintiff's client had advised and caused the client to dismiss the plaintiff and deprive him of the fee he was to have received under his contingent fee contract. ${ }^{2}$ The defendant's demurrer to the complaint was sustained by the trial court. The California Supreme Court reversed, with directions to overrule the demurrer. The court held that the plaintiff's allegations had stated a cause of action because defendant's intentional interference was unjustified.

In recent years a number of suits have been brought by attorneys seeking to recover damages from third persons who, in effecting settlements, have induced breach of contingent fee contracts. ${ }^{3}$ Several jurisdictions, including California, have recognized the attorney's cause of action. ${ }^{4}$ This position is consistent with the increasingly wide judicial

\footnotetext{
${ }_{14}$ Cal. Rptr. 294 (Sup. Ct. $196 \mathrm{z}$ ).

3 "Plaintiffs were to advance all expenses necessary for the preparation of the case and for court costs and were to receive one third of the amount of the recovery remaining after deduction of the costs." Id. at 295.

${ }^{8}$ See State Farm Fire Ins. Co. v. Gregory, I 84 F.2d 447 (4th Cir. 1950); Barnes v. Quigley, 49 A.2d 467 (D.C. Munic. Ct. App. 1946); Employers Cas. Co. v. Moore, 60 Ariz. 544, 142 P.2d 414 (1943); Freed-v. Manchester Service, 165 Cal. App. 2d 186, 33 I P.2d 689 (Dist. Ct. App. 1958); Tauro v. General Acc. Fire \& Life Assur. Corp., 297 Mass. 234, 8 N.E.2d 773 (1937); Herbits v. Constitution Indem. Co., 279 Mass. 539, 18 I N.E. 723 (1932); Krause v. Hartford Acc. \& Indem. Co., 331 Mich. 19, 49 N.W.2d 4I (195I); Lurie v. New Amsterdam Cas. Co., 270 N.Y. 379, I N.E.2d 472 (1936); Gordon v. Mankoff, 146 Misc. 258, 261 N.Y. Supp. 888 (N.Y. City Ct. 193I); Neff v. Willmott, Roberts \& Looney, I70 Okla. 460, 41 P.2d 86 (1935); Wahl v. Strous, 344 Pa. 402, 25 A.2d 820 (1942); Keels v. Powell, 207 S.C. 97, 34 S.E.2d 482 (1945).

See also Employers Liab. Assur. Corp. v. Freeman, 229 F.2d 547 (10th Cir. 1955), in which the breach was not induced to effect a settlement, but to substitute defendant's agent for the plaintiff.

4 See State Farm Fire Ins. Co. v. Gregory, 184 F.2d 447 (4th Cir. 1950); Freed v. Manchester Service, 165 Cal. App. 2d 186, 331 P.2d 689, (Dist. Ct. App. 1958); Lurie v. New Amsterdam Cas. Co., 270 N.Y. 379, I N.E.2d 472 (1936); Gordon v. Mankoff, I46 Misc. 258, 261 N.Y. Supp. 888 (N.Y. City Ct. I931); Klauder v.
} 
recognition of tort liability for inducing breach of contract. ${ }^{5}$ Two arguments against recovery, however, have led some courts to deny the attorneys' cause of action. The first is that, because of the nature of attorney-client agreements, a third person not a party to the contract cannot cause a true breach of contract. ${ }^{6}$ The second is that third persons should be privileged to interfere with attorney-client contracts in effecting settlements. ${ }^{7}$

The argument that a third person cannot induce a true breach of an attorney-client contingent fee contract is based on the privilege of the client to dismiss his attorney at will. This position overlooks the fact that, despite the privilege of dismissal, a client does violate his contract if he fails to pay his attorney's fee. ${ }^{8}$ In attorneys' suits against their

Cregar, 327 Pa. 1, r92 Atl. 667 (1937); Keels v. Powell, 207 S.C. 97, 34 S.E.2d 482 (r945). Cf. Wahl v. Strous, $344 \mathrm{~Pa} .402,25$ A.2d 820 (x942) (Attorney's cause of action recognized, but plaintiff did not sustain burden of proof); Neff v. Willmott, Roberts \& Looney, I 7o Okla. 460, 4I P.2d 86 (I935) (cause of action recognized, but statute of limitations had run).

'The application of tort liability for interference with contractpal relations has been constantly expanded since the landmark case of Lumley v. Gye, $2 \mathrm{El}$. \& Bl. 2 16, I 18 Eng. Rep. 749 (Q.B. 1853). See generally Avins, Inducing the Termination of Contract, 24 TenN. L. Rev. 1089 (1957); Carpenter, Interference with Contract Relations, 4 I HARv. L. REv. 728 (1928); Harper, Interference with Contractual Relations, 47 Nw. U.L. REv. 873 (1953) (includes discussion of negligent interference); Sayre, Inducing Breach of Contract, 36 HARv. L. REv. $66_{3}$ (1923); Note, 32 B.U.L. REv. 214 (1952) (profitable relations); Note, 33 N.Y.U.L. REv. 238 ( I958) (at-will contracts); Note, 6 Rutgers L. REv. 475 (1952) (contractual negotiations).

- Tauro v. General Acc. Fire \& Life Assur. Corp., 297 Mass. 234, 8 N.E.2d 773 (1937); Herbits v. Constitution Indem. Co., 279 Mass. 539, 181 N.E. 723 (1932).

${ }^{7}$ See Krause v. Hartford Acc. \& Indem. Co., 33 I Mich. 19, 49 N.W.2d 4 I (I95I). Cf., Employer's Cas. Co. v. Moore, 6o Ariz. 544, I42 P.2d 4I4 (1943); Barnes v. Quigley, 49 A.2d 467 (D.C. Munic. Ct. App. 1946). In these cases the grounds for denying the attorneys' causes of action were not clearly set forth, but in each instance the court indicated that the defendant's action was not "unlawful interference."

8 "[An attorney's contingent fee contract] is a legal and valid contract entitled to the protection of the law, and an attorney who is wrongfully discharged is generally entitled to the same amount of compensation as if he had completed the contemplated services. . . . [Cases] which involve settlement by clients without the consent of their attorneys are distinguishable. In none of them were the clients induced, as a means of obtaining the settlements, to repudiate the contracts with their attorneys and to refuse to pay them. In the present case plaintiffs do not complain because there may have been a settlement but because defendants induced the [client] to repudiate the contract and deprive plaintiffs of its benefits." i4 Cal. Rptr. at 296.

It can be argued that the Massachusetts court, in the two cases cited in note 6 supra, held that the defendants had induced settlement only. However, the court did not distinguish settlement from breach. In both cases there were allegations to the effect that the plaintiff had been deprived of his fees, and that settlement had been induced with intent to deprive the plaintiff of his fees. The court in Herbits simply said that settle- 
clients, most jurisdictions allow attorneys to recover damages for breach of contingent fee agreements, ${ }^{9}$ and others allow recovery in quantum meruit. ${ }^{10}$ It is, of course, arguable that there is no breach of contract in jurisdictions that limit recovery to quantum meruit. Restitution, however, has long been considered an alternative remedy for breach of contract as well as a quasi-contractual remedy. ${ }^{11}$ Moreover, it would seem overly conceptualistic to predicate an attorney's recovery against a third person who interferes with a contingent fee agreement upon whether the attorney may sue his client in contract or must sue in quasicontract. ${ }^{12}$

In addition, it is questionable whether a finding that there has been no breach in the technical sense should be fatal to the plaintiff's case. ${ }^{13}$ Recovery is allowed for types of interference other than inducing breach. For example, courts allow recovery for inducing termination of

ment was not breach. In Tauro the court held that the "facts alleged do not warrant the conclusion that the client broke his contract with the plaintiff."

${ }^{\circ}$ See, e.g., Weil v. Fineran, 78 Ark. 87, 93 S.W. 568 (1906); Echlin v. Superior Ct., ${ }_{3}$ Cal. 2d 368, 90 P.2d 63 (1939); Goldberg v. Perlmutter, 308 Ill. App. 84, 31 N.E.2d 333 (1941); French v. Cunningham, 149 Ind. 632, 49 N.E. 797 (1898); Carter v. Dunham, 104 Kan. 59, 177 Pac. 533 (1919); Simon v. Chicago, M. \& St. P. Ry., 45 N.D. 251, 177 N.W. 107 (1920); Harrison v. Johnson, 64 Ohio App. 185, 28 N.E.2d 615 ( 1940$)$; First Nat. Bank \& Trust Co. v. Bassett, 183 Okla. 592, 83 P.2d 837 (1938); Dolph v. Speckart, 94 Ore. 550, 186 Pac. 32 (1920); Williams v. Philadelphia, 208 Pa. 282, 57 Atl. 578 (1904); Brownlow v. Payne, 2 Tenn. App. 154 (1925); White v. Burch, 19 S.W.2d 404 (Tex. Civ. App. 1929); Hamlin v. Case \& Case, $\times 88$ Wash. $x 50,6 \times$ P.2d $\times 287$ (1936); Clayton v. Martin, 108 W.Va. 571. 151 S.E. $855(1930)$.

${ }^{10}$ See, e.g., Cole v. Myers, 128 Conn. 223, 21 A.2d 396 (1941); Hubbard v. Goffinett, 253 Ky. 779, 70 S.W.2d 671 (x934); Pye v. Diebold, 204 Minn. 319, 283 N.W. 487 (1939); Harris v. Root, 28 Mont. 159, 72 Pac. 429 (1903); Martin v. Camp, 219 N.Y. $170, \times 14$ N.E. $46(19 \times 6)$.

ii See 5 Corbin, Contracts $\S \S$ x 102-21 (195x).

${ }^{12}$ In New York, where attorneys are restricted to the quantum meruit remedy in suits against their clients, the Court of Appeals has taken the sensible and consistent view that the attorney who recovers from a third person for inducing a breach of a contingent fee agreement is limited to a quantum meruit measure of damages. Lurie v. New Amsterdam Cas. Co., 270 N.Y. 379 , x N.E.2d 472 ( $x 936$ ).

${ }^{13}$ Plaintiffs have recovered from third persons who interfered with contracts unenforceable for uncertainty or within the Statute of Frauds or statute of limitations. See Romano v. Wilbur Ellis \& Co., 82 Cal. App. 2d 670, r86 P.2d xo12 (1948); Aalfo Co. v. Kinney, 105 N.J.L. 345,144 Atl. $7 \times 5$ (1929); Ringler v. Ruby, 117 Ore. 455 , 244 Pac. 509 (1926); Bitzke v. Folger, 23 I Wis. 513, 286 N.W. $3^{6}$ (1939). Promisors have recovered for conduct making performance more onerous. McNary v. Clamberlain, 34 Conn. 384 ( 1867 ); Morris v. Blume, 55 N.Y.S.2d 196 (Sup. Ct. x945), aff'd 269 App. Div. 832, 56 N.Y.S.2d 414 (1945). See generally I HARPER \& JAMES, TORTS $\S 6.9\left(x_{956)}\right.$. 
contracts terminable at will. ${ }^{14}$ Indeed, the tort is becoming known as "interference with contractual relations."

The second argument, that third persons effecting settlements should be privileged to induce a breach of an attorney-client fee contract, ${ }^{15}$ is based on the policy of the law to encourage settlements. ${ }^{16}$ The question of whether such a privilege should be recognized involves a balancing of interests. The social utility of the interest which the privilege promotes must be greater than the social utility of protecting the interest of the injured party to the contract. ${ }^{17}$ Thus, in the instant case the social utility of settlements and the extent to which the recognition of a privilege would promote settlement must be weighed against that of attorney's contingent fee contracts and the attorney-client relation.

It is believed that the court was correct in refusing to recognize a privilege in the defendant in the Herron case. How little such a privilege would further settlements is seen when it is compared with the result obtained by the court. Under Ferron, third persons retain the right to settle their disputes, but are restrained from resorting to the tactic of inducing a client not to pay his attorney. ${ }^{18}$ As a client does not break his fee contract when he settles his dispute, ${ }^{19}$ but only when he

${ }^{14}$ Speegle v. Board of Fire Underwriters, 29 Cal. 2d 34, r72 P.2d 867 (1946); Wilkinson v. Powe, 300 Mich. 275, I N.W.2d 539 (1942); A.S. Rampell, Inc. v. Hyster Co., 3 N.Y.2d 369, I44 N.E.2d 37 I (r957); REstatement, Torts $\$ 766$, comment $c$ (r939); Avins, Inducing the Termination of Contract, 24 TENN. L. REv. 1089 (1957).

${ }_{10}$ See cases cited in note 7 supra.

${ }^{10}$ The policy of the law to further settlements is manifested in rules such as the one prohibiting the use of offers to settle as admissions of liability in a subsequent suit on the claim. See generally is AM. JuR. Compromise and Settlement $\$ 4$ (I937). For discussion of the value of settlements see Brady, The Settlement of Controversies: The Will and the Way To Prevent Lawsuits, 45 A.B.A.J. 47 I (I959); Brown, Court Congestion: Is Settlement the Key?, 35 Los ANgeles B. Bull. 3 (1959).

${ }^{17}$ See I HARPER \& JAMES, TORTS § 6.12 (1956).

${ }^{18}$ See Gordon v. Mankoff, 146 Misc. 258, 261 N.Y. Supp. 888 (N.Y. City Ct. I93 I) ; Keels v. Powell, 207 S.C. 97, 34 S.E.2d 482 (I945).

Of course, one is never privileged to induce a breach of contract by certain conduct, such as fraudulent misrepresentation or physical violence. See RESTATEMENT, TORTS $\$ 767$, comment $b$ ( 1939 ).

${ }_{10}$ The contingent fee contract in the Herron case included a clause in which the client had agreed not to settle without the plaintiff's permission. The court did not pass upon the validity of this clause. Such clauses have appeared in several of the fee agreements in the cases under discussion, but, as in Herron, no decision has turned on their breach.

The jurisdictions are split on the validity of these clauses. All jurisdictions, however, will allow attorneys to recover in quantum meruit when these agreements are broken. Nevertheless, some jurisdictions that have held these agreements invalid have also held 
does not pay his lawyer's fee, ${ }^{20}$ there is no danger under Herron that one who has induced a client to settle by other means can be said to have induced a breach of contract. ${ }^{21}$ In addition, there is little danger that legitimate settlements will be discouraged from fear of a jury risk. In order to recover, the attorney must prove that the third person intentionally induced the client to violate the fee agreement. ${ }^{22}$

Because of the broad scope for settlement under Herron and other decisions that recognize a cause of action, it is obvious that the asserted privilege actually furthers settlement very little. In addition, when it is recogmized that every dispute settled by inducing a client to breach his contract with his attorney creates a new dispute between the attorney and his client, ${ }^{23}$ it becomes questionable whether the privilege furthers settlement at all. Therefore, when weighed against the disruption of attorney-client relations which the privilege invites, neither the privilege nor any settlement it promotes is worthy of judicial sanction. ${ }^{24}$

the contingent fee contracts of which they are a part invalid. See generally Annot., 121 A.L.R. I122 (1939). In such jurisdictions there would seem to be an increased conceptualistic problem of finding a breach. Furthermore, it would seem inconsistent not to allow third persons a privilege to induce a breach of such agreements.

20 "The client cannot, by settling, compromising, or dismissing his suit ... without the consent of or over the objection of his attorney, deprive the attorney of his compensation for the agreed amount. 5 AM. JUR. Attorneys at Law \$ 173 (1936).

${ }^{2 x}$ There may be, however, a problem of proving intent. The person who induces a settlement, by whatever means, with the desire to deprive the attorney of his fee under a contract should be liable. The difficult case involves the third person who does not desire the breach, but is virtually certain it will result from his settlement with the client. One line of authority, not specifically involving attorney-client contracts, treats the breach in these situations as too "remote." Prosser suggests that the incidental nature of the breach should be a factor in granting the third person a privilege in these situations. PROSSER, TORTS 734-35 (1955).

${ }^{22}$ This burden is extremely difficult to fulfill unless a witness to the settlement agreement can be found who will so testify. See Klauder v. Cregar, 327 Pa. I, 192 Atl. 667 (1937).

28 "The conduct of an insurance company in inducing an injured person to repudiate his contract with an attorney may be detrimental not only to the interests of the attorney but also to the interests of the client since ... the client, in addition to being deprived of the aid and advice of his attorney, may also be liable for the full contract fee." 14 Cal. Rptr. at 297.

See notes 9, 10, and 20 supra.

24 "Aside from the matter of securing for the attorney his compensation, which is important enough, there is the more far-reaching effect upon the administration of justice as a whole to consider, if parties to a suit were to be allowed to ignore counsel and effect settlements behind his back. The deteriorating effect upon the entire system of judicial administration which would follow such a course of action oft repented is obvious.

"From time immemorial, the relationship between attorney and client ... has enjoyed a peculiar and protected status in the law. It is rightly regarded as a unique 
The two arguments examined do not provide a sound basis on which to deny the attorney's cause of action against third persons who interfere with the attorney's contingent fee contract. Rather, the Herron decision and other cases recognizing the attorney's cause of action have correctly applied the tort theory of liability for inducing breach of contract.

and confidential relationship. It necessarily implies a special trust and confidence among its participants; and the law looks with jealous concern upon the protection of the relation and deplores incidents between attorney and client which lead to suit. To open the door to outside parties wantonly to come in and negotiate the destruction of the relationship would bode no good for either the practitioner, client, or the public as a whole." Blackwell, Interference with Contract for Attorney's Fees as Cause of Action, 9 U.S.C. SELdEN SoC. YeAR BoOK 3I, 35 (1948). 